\title{
SOLUSI KONFLIK AGAMA DI MEDIA SOSIAL
}

\author{
Jarir \\ Manajemen Dakwah di STAIN Bengkalis \\ Email:jaringmail.com
}

\begin{abstract}
Abstrak
Perkembangan teknologi komunikasi, khususnya gajet, semakin pesat. Apa yang terjadi di sudut negeri ini, babkan di sudut dunia, dengan mudah terkirim melalaui jari-jemari kita. Dunia ibarat dalam genggaman jari, semua akan mudah diekses. Kemudah-kemudahan ini yang menyebabkan apa yang ada di kepala kita, langsung kita upload, tidak sadar babwa apa yang dalam pikiran kita itu bisa menyebabkan orang lain tersinggung. Di sinilah awal muasal konflik agama di media sosial (medsos) itu bermula. Solusinya, ada dua alternative, pertama jalur bukum. Yakni melalui supremasi bukum, yakni mengikat pelakunya dengan KUHP dan UU ITE. No19/2016, namun jalur bukum ini hanya sifatnya shock terapy, kadang malah membuat luka antar-umat beragama semakin lebar. Kedua, melalui jalan damai. Di sinilah peranan tokoh masyarakat dan ormas untuk saling memahami, bahwa kita hidup di ruang bersama yakni ruang kebangsaan.
\end{abstract}

Kata kunci; Konflik, agama, medsos

\section{Pendahuluan}

Dunia virtual (dunia maya) dalam bentuk facebook, twitter, whats upp, instagram, skeype, $B B M$, dan lainnya, saat ini sangat besar dampaknya bagi kehidupan manusia. Manusia berinteraksi dengan manusia lainnya di belahan bumi ini, hanya dengan tekanan jari. Dunia ada di genggaman tangan, ada yang menyebut dunia "dalam tekanan jempol". Cukup tekan ini dan itu, maka kita bisa berteman dengan manusia di mana pun di belahan dunia ini.

Makanya, ada yang berpendapat bahwa dunia virtual membuat batas-batas negara tidak lagi menjadi hambatan dalam berdiskusi. Hal ini sebagaimana diprediksi Kenichi Ohmae (lahir 1943) dengan sebutan The End of The Nation State, masa berakhirnya batas-batas negara, disebabkan jaringan komunikasi internet lebih berpengaruh dari negara.

Teori Kenichi memang diarahkan pada besarnya peran kapitalis (bisnis) dalam membangun bisnisnya, sehingga negara tidak menjadi batasan dalam menyebarkan usahanya, namun teori ini juga terjadi pada bidang sosial dan politik. Politik yang terjadi di suatu negara akan mudah menyebar di negara lain disebabkan medis sosial yang kini sudah dalam genggaman setiap warga di belahan bumi ini, mulai yang di ujung pulau sampai di pegunungan, bahkan di pulau terpencil pun mereka bisa ekses informasi politik terkini. 
Peran Medsos sangat banyak, di antaranya sebagai sarana diskusi dengan jangkauan luas, bertukar informasi, sarana hiburan, sarana komunikasi, mempererat pertemanan dalam cakupan teman sekerja, sekolah, sekampung dan lainnya. Menjaling kembali pertemanan yang pernah putus misalnya teman lama, memperoleh informasi terbaru (aktual) dalam kehidupan sehari-hari dalam berbagai bidang kehidupan, mengisi waktu luang, menambah wawasan, pembelajaran, mendengarkan keluhan orang, memahami beragam karakter manusia, membangun hubungan dengan dunia yang luas, menjangkau dunia global dalam beragam sisi kehidupan.

Medsos sebagai sarana diskusi, tak jarang diskusi yang yang terjadi di ruang medsos bukan hanya soal hal-hal yang sederhana, tetapi juga masalah ekonomi, politik dan masalah agama. Disebabkan diskusi di medsos dihadiri bukan hanya dari kalangan mereka yang berpendidikan tinggi seperti profesor atau ulama besar, tetapi mereka yang tamat SD dan lainnya ikut urung rembuk dalam diskusi di medsos tersebut.

Disebabkan ketimpangan pendidikan, dan juga pengalaman beragama, maka pemikiran yang disampaikan seorang dosen yang bertitel Prof Dr, atau ulama yang bergelar Kiyai Haji $(\mathrm{KH})$, kadang disikapi yang sudut pandang berbeda (oleh orang yang level pendidikannya jauh di bawah mereka), sehingga memunculkan perbedaan pendapat yang menimbulkan gesekan (konflik), atau klaim kebenaran.

Cara kerja medsos seperti Facebook, Twitter dan Instagram menggunakan hukum logaritma, sehingga dengan sendirinya fosting yang disampaikan seseorang akan mengundang tanggapan dapaty berupa like atau sejenisnnya acungan jempol, suka dengan gamba hati, bahkan juga bisa berupa kritikan dan tanggapan yang kadang menyakitkan bagi yang ditanggapi. Dengan menggunakan hukum Logaritme, Facebook mendeteksi minat user dari topik apa saja yang biasa dibagikan atau disukai. Mendeteksi durasi yang dihabiskan pada post-post tertentu yang nantinya akan dikenali sebagai topik yang menarik perhatian user. Twitter juga menerapkan fitur While You Were Away juga berdasarkan pada engagement terhadap seorang user atau topik-topik tertentu yang kita bicarakan di timeline. Hal ini memungkinkan user untuk tetap melihat twit dari user lain maupun topik tertentu yang ingin mereka ketahui. Demikian juga youtube, google, yahoo, mereka menggunakan teori logaritma, sehingga kencenderungan user dipahami dan membentuk jaringan yang lebih luas, teori persamaan dan ketidaksamaan.

Perselisihan pun sering disebabkan perbedaan aliran pemikiran, aliran politik, ideologis, bahkan perdebatan dalam diskusi di Medsos ini disebabkan perbedaan tingkat ekonomi, karena tingkat perbedaan-perbedaan itu mempengaruhi "rasa" dan bentuk pemahalam yang 
berbeda terhadap suatu konteks masalah atau pernyataan. Teori determinisme, bahwa pemikiran seseorang sangat dipengaruhi konteks lingkungan saat itu, lingkungan bisa berupa pemikiran atau lingkungan nonfisik.

\section{Ragam Bentuk Konflik Agama di Medsos}

Kasus penistaan agama di medis yang sudah lama terjadi, yakni Arswendo Atmowiloto, penulis yang dijeboloskan penjara karena survei tabloid Monitor, 1990. Penulis dan wartawan Arswendo Atmowiloto dipenjara selama empat tahun enam bulan, keputusan banding di Pengadilan Tinggi dan Mahkahmah Agung, terkait survei untuk tabloid Monitor dengan lebih 33.000 kartu pos dari pembaca. Dalam survei tokoh pilihan pembaca tersebut, Presiden Soeharto kala itu berada di tempat pertama sementara Nabi Muhammad di urutan ke-11. Survei ini menimbulkan aksi massa (www.kompasiana.com).

Kemudian Lia Aminudin, atau Lia Eden - mengaku sebagai imam Mahdi dan mendapat wahyu dari malaikat Jibril, 2006. Kasus ini sempat menggemparkan, karena pengikutnya semakin bertambah.

Kasus penistaan agama yang pernah santer dan menyebar luas adalah kasus penistaan agama oleh Basuki Tjahaja Purnama (Ahok), yakni Gubernur Jakarta. Kasus Ahok ini menjadi viral sejak diupload ke medsos, dan akhirnya Ahok pun diputuskan oleh majelis hakim dua tahun penjara. Kasus ini banyak menyita perhatian publik, ribuan umat Islam melakukan aksi damai agar kasus penistaan agama diselesaikan seadilasilnya. Konflik pun muncul di medsos, mereka yang menginginkan keadilan dianggap pula tidak pro-NKRI atau tidak memahami kebhinnekaan negeri ini. Tentunya update status masing-masing user medsos terkait kasus Ahok ini menimbulkan gesekan yang menimbulkan potensi konflik, bahkan bisa dikatakan konflik dalam bentuk verbal.

Kasus Ahok ini menarik, konflik verbal bukan antar-agama, tetapi internal agama, yakni sesama pemeluk agama Islam, ini yang lebih panas dan berjalan alot. Konflik di internal agama Islam ini yang paling seru, bukan hanya melibatkan muslim lapis bawah, tetapi juga ulama besar, sehingga memunculkan gap dan bahasa kebencian masing-masing pihak. Bahkan potensi konflik ini menyebar ke aspek lain, misalnya pihak pemerintah yang berkuasa (Presiden Joko Widodo) dianggap terlalu campur tangan, adanya tangan besar (ketua partai) yang ikut bermain, pihak Polri yang dianggap tidak netral, bahkan lembaga yang terkait dengan peradilan pun menjadi sasaran seperti jaksa penuntut umum yang dinilai menuntut Ahok terlalu ringan. Terus bergulir, masing-masing pendukung melakukan gerakan, yang dinyatakan dalam medsos dengan ragam bentuk dan sampai kini kasus Ahok ini tetap menjadi isu yang menarik. 
Fenomena Nusron Wahid misalnya, di mana sosok tokoh Pemuda Anshor terang-terangan mendukung Ahok saat diskusi ILC di Tv One, sehingga medsos pun ramai dengan fenomena Nusran Wahid. Berikutnya muncul tudingan bahwa umat Islam yang melakukan aksi demo damai dianggap anti-bhinneka tunggal ika, mereka dianggap menghendaki syariat Islam ditegakkan di negeri ini atau anti-NKRI. Persoal seputar kasus Ahok ini berujung pada rencana pembubaran HTI di Indonesia. Banyak aspek yang terkait dengan Ahok ini telah menguras banyak energi dan waktu anak bangsa di negeri ini, namun diprediksi kasus ini meluas karena masing-masing kubu dengan tokoh-tokoh besar di baliknya tetap melakukan perlawanan, dengan semangat saling menyerang.

Tidak adil rasanya jika medsos dianggap biang keladi munculnya konflik agama semata, medsos juga berhasil membangun kearifan beragama, namun karena tulisan orang lain dilihat dari sisi sudut pandang konflik agama, maka lebih banyak muatan konflik agamanya. Diskusi melalui medsos akan memberikan nuansa yang baru, karena masing-masing pihak berargumen dengan landasan teori yang berbeda.

Di sinilah titik temu dialog lintas pemikiran, bagi mereka yang mau menemukan titik temu. Namun bagi mereka yang tetap bersekukuh dengan pendapatkannya, apa pun alasan pihak lawan, dia tetap tidak bisa menerimanya.
Belum lama ini, juga terjadi dugaan penistaan agama yang dilakukan seorang pemuda di Pekanbaru, dia meng-update pemikirannya dengan kata-kata yang yang menunjukkan kebencian pada agama Islam. Akhirnya pemuda ini diamankan di Mapolda Riau, dan pihak keluarga (orang tua pemuda) pun memohon maaf atas apa yang dilakukan anaknya.

Pelaku penistaan agama di medsos yang ditangkap Polres Banyuwangi. Pelaku dugaan penistaan agama diamankan Polres Banyuwangi, Jumat (17/6/2016). Bagus Panji (23) warga Benelan Lor, Kecamatan Kabat, ditangkap karena ulahnya memposting status di media sosial, menghina agama Islam dan Nabi Muhammad, Ahad (12/6).

Pelaku mengunggah status tersebut lantaran sakit hati melihat pemberitaan razia pedagang yang dilakukan Satpol PP di wilayah Serang, Banten.Postingaan tersebut kemudian memicu kecaman dari masyarakat hingga organisasi Islam di Banyuwangi.

Kapolres Banyuwangi, AKBP Budi Mulyanto ada beberapa organisasi yang melaporkan tersangka. Pelaku akhirnya ditangkap di rumahnya. Pasal yang dikenakan yakni pasal 45 jo pasal 27, serta pasal 28 UU No. 11 tahun 2008 tentang informasi dan transaksi elektronik (ITE). Juga dinilai melanggar Pasal 156a KUHP. Tindakan pelaku melanggar UU ITE. Ancamannya 6 tahun penjara. Bagus Panji meminta maaf kepada pengguna media 
sosial maupun umat Islam. Apa yang dilakukannya ini merupakan kelalaiannya (www.boombastis.com).

Contoh lain, kasus yang terjadi di Palu Sulawesi Tengah. Keluarga I Wayan Hery $\mathrm{C}$ tersangka kasus penistaan agama melalui media sosial di Kota Palu beberapa hari lalu, meminta maaf dan berjanji tidak akan melakukan hal tersebut. Juru bicara Polda Sulawesi Tengah AKBP Utoro Saputro di Palu, Rabu. Meski sudah meminta maaf, namun proses hukum terhadap kasus tersebut tetap dilakukan karena perbuatannya melanggar UndangUndang Informasi teknologi dan pasal 156 KUHP karena celotehnya di media sosial yang dianggap bisa mengajak permusuhan di depan umum (www.kompasiana.com).

Beberpa kasus penistaan agama yang dilakukan oleh pemeluk agamanya sendiri (inter umat beragama). Misalnya pada tahun 2013 lalu, ada video yang diunggah ke media sosial dengan memperlihatkan beberapa siswi yang diduga bersekolah di SMA Negeri 2 Toli-toli sedang bersenda gurau memperagakan gerakan salat disertai dengan berjoget, gerakan tak senonoh, menjulurkan lidah dan tertawa-tawa.

Ada juga dilakukan sejumlah pemuda dengan memperagakan gerakan salat yang kabarnya dilakukan di sebuah masjid. Para pemuda ini memperagakan gerakan shalat dengan bertelanjang dada dan sampai mempelorotkan celana mereka. Foto-foto mereka menjadi viral setelah salah satu pemilik akun Facebook dari Lampung mempostingnya di media sosial.

Kasus lainya, melecehkan gerakan salat dengan cara tak senonoh, yakni sejumlah pemuda yang diperkirakan dari Kecamatan Banyuates, Kabupaten Sampang, Madura tengah memperagakan gerakan salat di jalanan. Bahkan, salah satu dari mereka nampak bercanda dengan melakukan gerakan hubungan badan terhadap sang imam. Diduga, para pelakunya adalah salah satu geng motor yang cukup terkenal di Pulau Garam tersebut.

Ada juga yang melakukan gerakan salat dengan merokok. Yakni oleh tiga remaja yang fotonya beredar di media sosial pada tahun 2016 ini. Dalam foto tersebut, ketiga remaja itu nampak melakukan gerakan salat di jalanan dan dua di antaranya nampak sedang menggigit rokok di bibirnya.

Kemudian pada April 2016, sebuah akun bernama Berita Heboh dan Langka mengunggah video beberapa remaja yang dianggap melecehkan gerakan salat. Dianggap melecehkan karena dalam video tersebut terlihat remaj-remaja yang ada di tempat itu memang mengenakan pakaian rapi dan memakai sarung, namun setiap kali akan melakukan gerakan salat, mereka langsung melompat-lompat. bahkan kalimat dan gerakannya juga terlihat dibuat-buat (www.boombastis.com).

Ada prediksi bahwa kasus penistaan agama dilakukan secara terorganisir, 
seperti kasus Saracen. Dari hasil penyelidikan forensik digital, terungkap sindikat ini menggunakan grup Facebook di antaranya Saracen News, Saracen Cyber Team, dan Saracennews.com untuk menggalang lebih dari 800.000 akun, kata polisi. Selanjutnya pelaku mengunggah konten provokatif bernuansa SARA dengan mengikuti perkembangan tren di media sosial, kata polisi pula.

Unggahan tersebut berupa kata-kata, narasi, maupun meme yang tampilannya mengarahkan opini pembaca untuk berpandangan negatif terhadap kelompok masyarakat lain.

Modusnya, sindikat yang beraksi sejak November 2015 tersebut mengirimkan proposal kepada sejumlah pihak, kemudian menawarkan jasa penyebaran ujaran kebencian bernuansa SARA di media social (www.bbc.com).

\section{Isu Agama; Perekat atau Ancaman?}

Menurut Ibn Khaldun (1986:151) mengapa isu agama selalu menjadi perhatian publik, dan langsung mendapat dukungan dan perhatian, karena agama tidak mengenal batas wilayah, suku, darah.

Dalam ajaran Islam, yang mulia itu adalah yang bertaqwa. Mulai dari penjuru negeri sampai ujung teluk, mereka semua bersaudara, diikat dengan aqidah dan ketaqwaan. Makanya, jika muncul ada kasus penistaan agama, mereka yang merespon bukan hanya dari satu provinsi, tetapi dari berbagai provinsi, kabupaten, kota di negeri ini. Misalnya kasus Ahok, yang merespon dan melakukan aksi damai bukan hanya dari warga Jakarta, tetapi dari Aceh, Medan, Padang, Riau, beberapa kota di Kalimantan dan wilayah di Jawa. Mereka ikhlas berkorban uang, waktu, dan meninggalkan anak istri, demi untuk aksi damai.

Islam sebagai agama yang dianut oleh mayoritas penduduk Indonesia, sebenarnya potensi untuk merekat persatuan (Abdullah, 1997). Ini telah terbukti dengan semangat jihad pada masa penjajah Belanda, para pahlawan berhasil mengusir penjajah dari bumi pertiwi yang kita cintai ini. Sejarah mencatat perang Aceh itu disebut dengan Perang Sabi, artinya perang fi sabilillah. Yakni perang suci, jihad di jalan Allah.

Hikayat Perang Sabi ini ada dua bentuk, pertama bentuk, genre tambeh (nasehat dan peringatan) dan genre epos (hikayat tokoh). Jenis tambeh ditulis oleh ulama, ajakan agar perang melawan penjajah sebagai jihad di jalan Allah. Hikayat bentuk tambeh ini ditulis sekitar 1834, yakni berupa saduran dari Risalah Abdussamad al-Falimbani, Nashihatul Muslimin. Sedangkan Hikayat Perang Sabi dalam bentuk epos seperti Hikayat Prang Sigli (1878), Hikayat Perang Geudong (1889) dan masih ada yang lainnya (Ibrahim. 1992).

Demikian juga Sultan Agung dari Mataram, Pangeran Diponegoro, Imam Bonjol di Sumatera Barat, dengan semangat agama. Dengan semangat 
beragama mereka bisa menyatukan negeri ini, mengusir penjajah. Lalu pertanyaan muncul, mengapa saat ini, malah isu agama dianggap ancaman dalam menjaga kesatuan NKRI? Tentu yang bermasalah di sini adalah penguasa dan jajarannya, mungkin ada yang tidak adil, zalim dalam bentuk kebijakan atau semena-mena (mengambil kebijakan dengan rasa emosional) dan lainnya, yang menyebabkan munculnya aksi perlawanan.

Beberapa kasus konflik agama yang viral di medsos umumnya diawali kasus sederhana, kemudian menjalar ke kasus lebih luas, yakni kebijakan pemerintah yang berkuasa. Jika pemerintah tidak bisa mengelola konflik itu, maka aksi lebih luas menjalar ke ranah politik dan ideologis. Ingat, Arab Spring (musim semi Arab) atau kebangkitan dunia Arab, diawali dari aksi penjual buah. Kelihatan sederhana, namun nilai-nilai yang diperjuangkan universal, yakni soal ketidakadilan rezim yang berkuasa.

Konflik agama biasanya tidak terlepas dari faktor ketidakadilan rezim, ketidakdemokrasian rezim di suatu negara. Agama sebagai ajaran yang mensyariatkan nilai-nilai keadilan, kedamaian, menjadi perekat untuk melakukan perlawanan pada pemerintah. Misalnya melihat kasus rencana pembubaran HTI. Awalnya kasus ini dianggap ancaman bagi kelompok HTI, namun bagi kalangan pengamat hukum, pembubaran tidak bisa langsung dilakukan oleh pemerintah, tetapi oleh pengadilan. Itulah mekanisme negara hukum. Kesan yang muncul di publik bahwa pemerintah melakukan tindakan hukum pada ormas dengan pendekatan "suka tidak suka". Nah, maka kasus HTI ini menjadi perhatian pangamat hukum Prof Dr Yusril Ihza Mahendra yang menilai bahwa ini ketidakdilan. Kini kasus ini di medsos, kasus ini menjadi viral.

Dari beberapa kasus tersebut tergambar bahwa isu agama di Medsos bisa menjadi perekat kesatuan bangsa, namun bisa juga menjadi ancaman. Medsos cerminan kondisi umat, kondisi bangsa, kondisi negara, kondisi masyarakat dan kondisi lainnya. Jika muncul konflik agama, maka yang salah bukan Medsos, tetapi realitas kehidupan itu sendiri. Medsos ibarat cermin, ia hanya memantulkan realitas kehidupan.

\section{Perlu Penegakan Hukum}

Untuk mengatasi konflik agama di medsos hendaknya pemerintah tegas dalam menegakkan hukum. Jika hanya imbauan saja tidak cukup, seperti imbauan pemrintah dalam hal ini Menkoinfo, ulama, atau tokoh masyarakat agar arif dalam bermedia sosial. Warga netizen, mereka beragam latar belakang pendidikan dan tingkat sosialnya berbeda-beda, sehingga imbauan bagi sebagain mereka dianggap hal biasa, perlu penegakan hukum, agar mereka sadar bahwa apa yang mereka lakukan itu salah.

Sanksi hukum pidana (KUHP) seperti tentang Penghinaan Pasal 310 sanksi hukuman 9 bulan penjara, fitnah Pasal 317 
(4 bulan), penghinaan kepala negara Pasal 134, 136 (6 tahun). penghinaan terhadap golongan tertentu Pasal 156 (5 tahun), penghinaan terhadap pemerintah Pasal 154 (5 tahun), pembocoran rahasia negara Pasal 112 (4 tahun), pornografi Pasal 282 (9 bulan). Selain KUHP, UU No.19/2016 tentang Perubahan UU No 11/2008 tentang ITE pasal 27 pidana 6 tahun atau denda 1 miliar.

Bahkan pemerintah dibolehkan melakukan pemutusan eksis terhadap dokumen elektronik yang melanggar hukum, ini dilakukan untuk melindungi kepentingan umum. Hal ini dijelaskan UU ITE No.19/2016 Pasal 40, Pemerintah melindungi kepentingan umum dari segala jenis gangguan sebagai akibat penyalahgunaan Informasi Elektronik dan Transaksi Elektronik yang mengganggu ketertiban umum, sesuai dengan ketentuan peraturan perundang-undangan.

Pemerintah wajib melakukan pencegahan penyebarluasan dan penggunaan Informasi Elektronik dan/atau Dokumen Elektronik yang memiliki muatan yang dilarang sesuai dengan ketentuan peraturan perundangundangan. (2b) Dalam melakukan pencegahan sebagaimana dimaksud pada ayat (2a), Pemerintah berwenang melakukan pemutusan akses dan/atau memerintahkan kepada Penyelenggara Sistem Elektronik untuk melakukan pemutusan akses terhadap Informasi Elektronik dan/atau Dokumen Elektronik yang memiliki muatan yang melanggar hukum.

Khusus penghinaan agama, secara tegas pada Pasal 40 dinyatakan bahwa setiap orang yang dengan sengaja dan tanpa hak menyebarkan informasi yang ditujukan untuk menimbulkan rasa kebencian atau permusuhan individu dan/atau kelompok masyarakat tertentu berdasarkan atas suku, agama, ras, dan antargolongan (SARA) sebagaimana dimaksud dalam Pasal 28 ayat (2) dipidana dengan pidana penjara paling lama 6 (enam) tahun dan/atau denda paling banyak Rp1.000.000.000,00 (satu miliar rupiah).

Berpijak pada UU ITE No.19/2016 ini maka aparat pemerintah bisa menindak siapapun yang melakukan penghinaan di medsos. Sanksi hukumnya lumayan berat, penjara enam tahun dan atau denda paling banyak Rp1 miliar. Namun realitasnya, hanya sedikit yang dijerat UU ini, pemerintah lebih mengedepankan imbauan daripada sanksi hukum.

Menurut pengamat media, bahwa saat salah seorang pengguna medsos dijerat hukum, pada saat itu aktivitas di medsos berubah menjadi santun. Aksi saling ejek langsung berkurang, walaupun di saat itu sebenarnya musim pemilihan umum, pemilihan gubernur atau pemilihan presiden. Ini artinya shock terapy itu perlu dilakukan oleh pemerintah, agar hukum dianggap tinggal di atas kertas, tidak pernah digunakan dalam menindak 
pengguna medsos yang semakin jauh dari etika berkomunikasi.

Biasanya aksi menghina agama bersamaan dengan penghinaan suku, dan antar-golongan, karena rasa bersama itu ada di suku, agama dan golongan. Dan jika pemerintah tidak mengambil sikap tegas, konflik tidak hanya di medsos, tetapi juga bisa mengarah ke dunia nyata.

\section{Damai Itu Lebih Indah}

Beberapa kasus konflik di media sosial, jika perspektif penegakan hukum, maka efeknya akan panjang, pihak yang merasa dirugikan, akan terasa lukanya masih panjang, dan berproses pada bentuk gesekan antar-kelompok atau agama, sehingga luka itu semakin melebar.

Ada beberapa alternatif dalam penangan konflik agama di medsos, salah satunya bentuk damai, yakni kesepatan dua belah pihak, untuk saling memahami dan pihak yang telah melakukan meminta maaf, mengakui kesalahannya dan tidak akan mengulanginya lagi. Demikian juga pihak-pihak yang merasa dirugikan memahami bahwa setiap manusia memiliki kelemahan, dan kekhilafan itu adalah alami, makanya memberi maaf kepada yang bersalah itu lebih baik, daripada memberikan sanksi hukum. Allah menyukai orang yang memberi maaf, dan Rasulullah SAW sendiri sering memberi maaf kepada orang kafir Quraisy walau mereka sangat kejam kepada Rasulullah, seperti Abu Sopyan yang dikenal sangat kejam kepada umat Islam saat Fathul
Makkah, Rasulullah mengajak Abu Sopyan masuk Islam dengan cara; Barang siapa yang masuk ke rumah Abu Sopyan, maka aman. Itulah kebesaran hati Rasulullah SAW.

Kita sebagai bangsa yang besar, dengan arti rakyatnya suka memberi maaf dan saling menyanyangi, maka sudah sepantasnya jalur damai (memberi maaf) itu lebih baik. Ada ruang besar tempat kita hidup bersama, yakni ruang kebangsaan. Kita hidup di ruang itu, seling segala perbedaan, kesalahan, bisa dimaafkan, karena kita bersama hidup di ruang itu.

Ada banyak perbedaan yang dimiliki penduduk negeri ini, mulai dari perbedaan suku, agama, bahasa, tempat tinggal (ada yang digunung, pesisi pulau, dan pulau), namun semua itu diperekat dengan hidup bersama di ruang kebangsaan. Ruang yang dianggap selama ini membuat hidup kita nyaman.

Walaupun memang kita berbeda dengan keragamaan perbedaan yang kita miliki, tetapi perbedaan akan menjadi indah saat kita hidup bersama. Dengan adanya ikatan Dasar Negara Pancasila, UU 1945 dasar hukum, dan tatanan kehidupan berbangsa lainnya, kebhinnekaan itu adanya tetap terpelihara.

Kini dengan maraknya kerawanan konflik di medsos, hendaknya kita menyadari bahwa kita hidup berbangsa di ruang yang sama, maka hendaknya dalam penegakan hukum mengedepankan jalur damai, sehingga tidak melukai mereka 
yang bersalah, dan melukaui mereka yang dirugikan. Hidup damai itu indah, mari tularkan semangat rahmatun lilalamin, sebagaimana diperankan Nabi Muhammad SAW dalam hidupnya.

\section{Kesimpulan}

Konflik agama di medsos semakin marak, dengan munculnya beragam kejadian yang sering melukai umat beragama. Sejalan dengan perkembangan teknologi, khususnya gajet, maka konflik di medsos ini akan semakin banyak jumlahnya. Bagaimana menekan angka konflik agama ini? Salah satunya dengan pegakan hukum, sebagaimana diatur dalam UU ITE No.19/2016, yakni ancaman hukuman enam tahun, dan atau denda maksimal Rp1 miliar.

Dengan adanya penegakan hukum, akan membuat jera mereka yang bermedia sosial. Saat polisi tegas menegakkan hukum, biasanya jumlah aksi saling mencela di medsos berkurang, namun tak lama berselang, kembali marak lagi.

Namun penegakkan hukum adalah solusi terakhir, negeri ini dikenal sebagai bangsa yang besar, dan berjiwa besar, maka alangkah baiknya jika penyelesaian masalah konflik agama di media sosial dengan cara damai. Karena jalur hukum membuat luka semakin lebar. Ada ruang berbangsa dan bernegara yang membuat kita hidup bersama, saling memahami, saling menghargai, sehingga perbedaanperbedaan itu bisa kita ikat bersama dengan cara saling memberi maaf. Di sinilah perlunya wawasan kebangsaan, sehingga kita hidup di ruang berbangsa dengan nyaman.*** 


\section{DAFTAR PUSTAKA}

Kenichi Ohmae, The End of the Nation State, The Rise of Regional Economies, The Free Press, Singapore, Copyrigh (C) 1995 by McKinsey \& Company Inc.

Noreena Hertz, The Silent Takeover: Global Capitalism and the Death of Democracy, William Heinemann (London), 2001.

Ibn Khaldun, Muqadimah, terj. Ahmadie Toha (Jakarta, Pustaka Firdaus, 1986),

Syamsuddin Abdullah, Agama dan Masyarakat, Pendekatan Sosiologi Agama, Jakarta, Logos, 1997.

Alfian T Ibrahim. 1992. Sastra Perang: Sebuah Pembicaraan Mengenai Hikayat Perang Sabil. Jakarta, Balai Pustaka.

"Middle East In Revolt". 10 Mei 2011, diakses tanggal 10 Mei 2017.

UU ITE No.19/2016 Pasal 40. Poin a dan b.

https://www.kompasiana.com/deandraku sumah/54f40fbe745513792b6c8506 /penistaan-agama-lewat-medsosharus-segera-ditertibkan, dieskses pada tanggal 22 Oktober 2018.

https://www.bbc.com/indonesia/trensosi al-41022914, diekses pada tanggal 22 Oktober 2018.

https://www.boombastis.com/pelecehanagama-islam/83067, diekses pada tanggal 22 Oktober 2018.

https://www.kompasiana.com/deandraku sumah/54f40fbe745513792b6c8506 /penistaan-agama-lewat-medsosharus-segera-ditertibkan. diekses pada tanggal 22 Oktober 2018.

https://www.boombastis.com/pelecehanagama-islam/83067, diekses pada 22 Oktober 2018. 